\title{
An Investigation of Teachers' Practice of Teaching Vocabulary in EFL Class: The Case of Otona Secondary School English Language Teachers
}

\author{
Abebayehu Anjulo Alaro \\ Department of English Language and Literature, Jinka University, Jinka, Ethiopia
}

\begin{abstract}
This study is aimed to investigate teachers' practice of teaching vocabulary in EFL classes. It was conducted at Otona Secondary School on English Language teachers. The descriptive research design was employed to achieve the intended aim of the study. In this study, 18 English language teachers were taken as participants through purposive sampling technique. Interview and classroom observation were used to collect data from the participant English language teachers. The data collected through interview and classroom observation were analyzed qualitatively based on the research objectives. The findings revealed that English language teachers did not give great emphasis on vocabulary instruction to create a participatory classroom through vocabulary lesson; as result, students could not engage new words in meaningful context. Based these findings, conclusions and recommendations were made.
\end{abstract}

Keywords: Teachers, Practice, Vocabulary, and Teaching

DOI: $10.7176 /$ JLLL/66-03

Publication date:March $31^{\text {st }} 2020$

\section{Introduction}

In EFL teaching classroom, the vocabulary instruction plays an important role to comprehend a text. It is a fact that vocabulary instruction has a paramount importance in English as a foreign language teaching context where students have limited access to learn the language. This is because vocabulary instruction can enhance students not only language proficiency but also other content related learning, and it helps to gain an understanding of the world, enabling them to think about and react to what they read, speak, write and listen (Nemati, 2009; and Siriwan, 2007). On the other hand, the effective vocabulary teaching instruction helps students' to practice wider or extensive independent reading in order to develop word knowledge instruction in specific words to enhance comprehension of texts containing those words instruction in independent word learning strategies, and word consciousness and word play activities to motivate and enhance learning ( Kamil, 2004; Schmitt, 2000; and Sthal, 2005).

The current education policy of Ethiopia concerns teaching English language as a subject and a medium of instruction in Secondary and higher education level as well (MOE, 2005). The education policy also needs teachers' help in vocabulary instruction to teach students' by creating greater opportunities that they critically comprehend a text. This indicates that vocabulary teaching practice is crucial for EFL teachers who are teaching English language so as to pay attention to students and the teaching methods. When EFL teachers are going to teach vocabulary lesson, they have to know about individuals' expectation, cultural background of learners and their prior knowledge of vocabulary (Hammerberg, 2004; and Piece and Fontaine, 2009). Thus, English language teachers should expect to identify the students' need in order to implement various activities through vocabulary lesson.

The practice of vocabulary teaching is a significant factor in language teaching, since words play an important role in expressing our feelings, emotions, and ideas to others during communication. It also helps English language teachers' to implement various vocabulary activities to advance students' productive ability in language skills. The practice that teachers implement various vocabulary activities in their language classes is to enhance their students' vocabulary knowledge or help them to be able to communicate by reading; speaking and writing on the basis of good command of vocabulary is very crucial (McCarten, 2007).

Presently, the vocabulary teaching practices seem to have received attention in Ethiopian in EFL classroom context. This is obviously exposed in generally in primary and secondary school levels. The practices of vocabulary teaching instructions are considered different teaching ways that teachers help students to get opportunities to practice new words implicitly as well as explicitly (MOE, 2005). Regarding this, teachers' discover a good access to teach students' vocabulary implicitly or explicitly via language skills. The teachers' focus should equip students' with various practice of vocabulary teaching, and give them many chance to practice new words to enhance their vocabulary knowledge (Stahl \& Kapinus, 2001). This needs EFL teachers' help to maximize students' ability in word power through the implementation of various vocabulary activities.

Thus, the ability to implement vocabulary instruction in English classroom is not simply undertaken in the traditional principles of language teaching. It needs English language teachers' actual classroom practices via 
vocabulary instruction. However, from researcher's personal observation in Otona Secondary School, English language teachers use various teaching methods to implement the vocabulary activities in English classroom to improve their students' capacity via vocabulary instruction, but students are unable to manipulate different vocabulary tasks in a purposeful communication. In addition to this, a research of this kind has not been carried out so far in that particular school. Unless this issue is investigated through research, it may be difficult to talk about the implementation of teaching vocabulary lessons in English classroom. Due to all these mentioned above, the researcher decided to conduct a systematic study on the practice of vocabulary teaching in EFL classroom.

Regarding this, some studies have been done in the practice of vocabulary teaching in the Ethiopian and international level. In Ethiopian level, Getachew (2014) conducted on vocabulary learning strategies used by EFL students: the Case of grade eleven high and low achievers at Jorgo Nole Preparatory School. The result indicated that there was a significant difference between the high and the low achievers regarding vocabulary learning strategies. Additionally, Minda (2003) The effectiveness of current vocabulary teaching techniques in facilitating production in junior secondary schools in Addis Ababa: grade seven in focus. The finding showed that the training has brought significant difference in the performance of students where the experimental groups have benefited. In international level, Rahimy and Shames (2012) conducted on an investigation of the effectiveness of vocabulary learning strategies on Iranian EFL learners' vocabulary test score. The findings showed a significant effect of vocabulary learning strategies on EFL learners' performance in a vocabulary test.

As far as the researcher's knowledge is concerned, the above studies were conducted in the area of the vocabulary teaching and learning strategies. In overall, the former studies were associated with the current study in that they were based on the issues of vocabulary learning strategies. However, their main purposes were not directly related with the aim of present study. Thus, the present study focused on an investigation of teachers' practice of teaching vocabulary in EFL classroom at Otona Secondary School English Language teachers'. The overall purpose of this study was to investigate the English language teachers' practice of teaching vocabulary in EFL class at Otona Secondary School. The specific objectives of this study were to investigate English language teachers' practice of teaching vocabulary in EFL classroom, and to examine the extent to which English language teachers encourage their students to learn vocabulary lesson.

\section{Material and Methods}

The researcher used the descriptive design to achieve the intended goal of the study. The reason why the researcher used the descriptive design is to describe about problems that exist; process that are going on; effects that are being felt; or trends that are developing (Cohen, Manion, and Morrison,2000). The focus of this study was to investigate the English language teachers' practice of teaching vocabulary in EFL class at Otona Secondary School. The participants of this study were Otona Secondary School EFL teachers. The researcher believed that the teachers' might have good awareness about the presence problem to offer information about vocabulary teaching practice in English classroom. Otona Secondary School (grade nine and grade ten) was selected to be the setting of the study. In this school, the total number of English teachers was 18. Thus, the researcher used a purposive sampling technique for this study to deliberately take 18 English language teachers who were teaching English in the school. The advantage of choosing a purposive sampling is that the researcher already knows something about the specific people or events and intentionally selects particular ones because they are seen as instances that are likely to produce the most valuable data (Denscombe, 2007).

To conduct the study the researcher employed both observation and interview in order to gather information regarding English language teachers' practice on teaching vocabulary lesson. The researcher used observation to investigate the teachers' practice on teaching vocabulary instruction in actual classroom. Regarding this, the researcher designed checklist to examine what was going on the actual classroom during English teachers' teaching vocabulary lesson. To avoid the potential personal bias during observation, the researcher chose three co-observers who were teaching English language at preparatory (grade $11 \& 12$ in Ethiopian context) education level. Moreover, the interview was also employed as data collection tool to gather necessary information from English teachers. Besides, the researcher used eight for interview to get first hand and genuine information from English Language teachers' to examine the extent to which they encourage their students to learn vocabulary lesson. Therefore, the researcher prepared semi-structured interview items for participant English teachers who were teaching in Otona Secondary School. Semi-structured interviews are useful when there is a need to collect in-depth information in a systematic manner from a number of respondents or interviewees (Creswell, 2003). This study was used the qualitative approach of data analysis. The data obtained through teachers' observation and interview was analyzed qualitatively in order to meet the research objectives

\section{Results}

\subsection{Teacher's practices in classroom vocabulary instruction}

One of the objectives of this study is to examine how EFL teachers' create various vocabularies learning situations in order to implement vocabulary lesson in EFL classroom to update students' desire in word power. Regarding 
this, the researcher obtained the relevant information through observation and interview from participant English language teachers. The researcher's first time observation result confirmed that from eighteen English Language teachers, only six teachers created good exposure for students to practice in a given vocabulary lesson. On the other hand, the other twelve teachers did not implement various vocabularies learning situation for students' participation in vocabulary lesson so as they used the old-fashioned method to teach students.

Additionally, there were ten English Language teachers' participated in-depth interviews. Although most of them agreed on the importance of practicing various vocabularies teaching context, the researcher did not see in his in-depth observation effectively their actual practice while they were teaching vocabulary lesson. This showed that the interview results had no consistency with the observation result. For example, the researcher made interview with participant teachers based on this theme.

Regarding this, four teachers said "we think the current vocabulary instruction can partially help students to develop possible vocabulary practice through learning cooperatively. That is because we have no sufficient time to create suitable vocabulary learning context for students' classroom participation...",

This idea was not supported by the classroom observation. Understanding various vocabularies teaching context is very important for students' classroom practice in vocabulary instruction that enable students' need to learn and to practice. On the other hand, the other two teachers said in the researcher's made interview:

"Vocabulary activities can help students to comprehend the important language skills in language learning. It exposes students at all levels and that they experience integrative language skills to improve their word powers through speaking, reading, writing and listening. They also said implementation of various vocabulary activities such as brainstorming, prefix, suffix, root study, stories, games, previewing in context, collocation, denotation, connotation and others can help students to maximize their word power.'

Regarding this, it is essential to expose the students to exercise various vocabularies learning activities in the target language in order to obtain new words. To accomplish this, multiple activities should be designed by English Language teachers to promote the classroom meaningful communication via vocabulary lesson. This can also create authentic new word learning situations where classroom activities take place.

\subsection{Teachers help students' to sort out new words from a text.}

In the practice of vocabulary teaching and learning process, teachers' support has a potential factor to motivate students that they sort out unfamiliar words from a given text and then they comprehend these words. According to the researcher observation, in Otona Secondary School context, a large numbers of EFL teachers did not give credit for students' motivation in order to comprehend unfamiliar words from the text. On the other hand, a few teachers motivate their students by facilitating activities such as, giving a list of words, making students to define the target word, making students to link the keyword with the meaning of the target word, and helping students to recall the meaning of the target word to have they find unfamiliar words from a given text to make better comprehension. This indicates that greater aspect is needed from English Language teachers to develop their students in word knowledge such as pronunciation, spelling, parts of speech, and collocation. It is assumed that when students do not sort out new vocabulary words from a given text, they simply need to practice the words some more. The similar result is also obtained from teachers' interview; most teachers informed that students are not as effective as they are anticipated to sort out unfamiliar words to comprehend the text. Teachers thought that the deficient classroom vocabulary instruction is resulted from learners' failure of concentration in a given vocabulary lesson. For example, six teachers said in similar way in their interview:

"There is a big problem that is the students have no background knowledge to sort out unfamiliar words from a given text to interact with a text. They also said there are very few students actively participate in vocabulary instruction that they have to integrate their background word capacity with the new one and the rest are observers."

This indicates that EFL teachers could not help students that they have to build their word power from the text though students' motivation is the base for vocabulary teaching and learning process. Unless enough support of teachers, it is very difficult to enable students to comprehend the text. In the other hand, four teachers said in their interview:

"It is possible to motivate students because teaches have skills and knowledge to help students that they sort out multiple new words from a given text but few teachers have no vision to encourage their students in a vocabulary lesson and they simply order students to discuss the activities either in pairs or in groups without telling them how they should discuss and what they should say and discuss together. In this regard, most students are passive in various moods of vocabulary lesson to identify key vocabulary activities in while reading passages and stories to maximize reading comprehension.",

As it is clearly indicated that students usually need further help from teachers in a vocabulary instruction, but 
the current vocabulary instruction is not enough to help students to develop their capacity of how to sort out unfamiliar words from a text. Learners benefit from being exposed to word meanings in multiple contexts. This can be accomplished in the classroom by providing a variety of vocabulary learning materials. To help the students English language teachers should provide activities that focus on the vocabulary learning lesson. Therefore, it is essential to expose the students to exercise various vocabularies learning activities in the target language in order to sort out new words from learning materials. To accomplish this, multiple activities should be designed by EFL teachers to promote the classrooms communication through vocabulary lesson. This can also create authentic new word learning situations where activities take place. However, some EFL teachers are exposed separable way with above interviewee opinion through the researcher's in-depth classroom observation. In accordance with this, the classroom conditions were supportive and attractive for the proper implementation of vocabulary learning activities, but teachers were not settling their classroom vocabulary tasks that include making classroom conditions helpful for effective implementation of vocabulary learning activities. They gave students long lists of vocabulary words with little or no context. So this is not effective way to teach students the vocabulary lesson and it also negatively affect students the production of word power. The interview data was contrasting with the classroom observation that participants in interview highlighted that as they use multiple vocabularies learning activities but in actual classroom they did not implement it. In line with this, few teachers also said in their interview:

"We create participatory vocabulary earning tasks for students, but students could not utilize their maximum potential of learning new vocabulary from the tasks. We provide various activities and examples of unfamiliar words in various contexts teaching integrative language skills though students are interested to participate in teachers' instruction effectively.',

As it was clearly stated that English language teachers might not be responsible for profession because they discourage their students that they taught the vocabulary lesson. This implies teachers did not follow the instruction to implement the vocabulary learning activities. Therefore, letting students to sort out new words teachers should draw students' attention on a particular word by writing the new words on the blackboard; the learner may focus on the meaning of a word by providing a definition or synonyms. Through this teachers can arouse students' attention towards vocabulary instruction.

\section{Discussions}

According to the results above, the vocabulary instruction being a useful approach to learn English language in more communicative way. Owing to the fact that vocabulary permeates listening, speaking, reading, and writing, it seems obvious that vocabulary learning is inseparable from the four skills in the language classroom. However, some English Language teachers are exposed separable way in the interviewee opinion through the researcher's in-depth classroom observation. In accordance with this, the classroom conditions were good for teaching and learning process, but teachers were not ready to implement vocabulary tasks for actual classroom practice. They gave students long lists of vocabulary words with no context. This is not effective way to teach students the vocabulary lesson and it can negatively affect students' production of word power. Therefore, Vocabulary activities are backbone for the development of any language, so English Language teachers should implement different vocabulary activities to accelerate students' capacity in word power (Walters, 2004). This idea is also supported by other scholars, it is impossible to teach a language without words, so English language teachers should take into account to find out the appropriate techniques to implement various vocabulary activities to develop students' classroom participation (Berne and Blachowicz, 2008). Additionally, students usually need further help from teachers in a vocabulary instruction to sort out new words, but most of teachers are not enough to help their students to develop their capacity of how to sort out unfamiliar words form a text. After learners are comfortable with a word's meaning, they can apply the meaning of the word to a new context (Curtis, 2006; Kamil, 2004 and Schmitt, 2000). This idea is also supported by the scholars, as they claimed that it is essential to expose the students to exercise various vocabularies learning activities in the target language in order to sort out new words from learning materials (Nation, 2001 and Nemati, 2009). To accomplish this, multiple activities should be designed by EFL teachers to promote the classrooms communication through vocabulary lesson. This can also create authentic word learning situations where activities take place.

\section{Conclusions}

The vocabulary instructions are very important for students' purposeful communications, but English language teachers did not provide enough vocabulary instructions to create participatory classroom situation. In addition to some English language teachers could not prepare vocabulary teaching lessons based on students' grade level text book, and they also did not appreciate their students' when they try to guess the meaning of new words. Unless teachers implement the vocabulary instruction in an appropriate way, this may negatively affect the students' further vocabulary practice. Therefore, students might be beneficiaries from the vocabulary instructions to develop their skills and strategies of vocabulary learning. 


\section{Recommendations}

Based on the conclusions drawn above, the researcher forwards the following recommendations as possible ways to address problems: English language teachers should create conducive atmosphere implementing various vocabulary learning instructions to create participatory classroom in order to appreciate their students when they attempt to guess new words. The students English text book contained various vocabulary learning activities, but English language teachers did not implement this in an appropriate context. So, teachers should teach their students by providing various vocabulary learning activities to help them to comprehend new words in appropriate context.

\section{References}

Berne, J. I. \& Blachowicz, C. L. Z. (2008). What Reading Teachers Say about Vocabulary Instruction: Voices from the Classroom? The Reading Teacher, 62 (4), pp. 314 - 323.

Cohen,L. Manion,L and Morrison,K.(2000). Reaserch Methods in Education. London and Newyork: Rutledge Flamer.

Creswell, J. W. (2003). Research Design: Quantitative, Qualitative, and Mixed Methods Approach (2 ${ }^{\text {nd }}$ Ed.). Thousand Oaks, CA: Sage

Curtis, M.E. (2006). The role of vocabulary instruction in adult basic education. In J. Comings, B. Garner, \& C. Smith (Eds.), Review of adult learning and literacy (Vol. 6, pp. 43-70). Mahwah, NJ: Lawrence Erlbaum Associates.

Denscombe, M. (2007). The Good Research Guide: For small-scale social research projects. (3 ${ }^{\text {rd }}$ Ed.). Open University: Open University press.

Dornyei, Z. (2007). Research Methods in Applied Linguistics: Qualitative, Quantitative and Mixed Methodologies. Oxford: Oxford University Press.

Getachew, B and Getachew, S. (2014). Vocabulary Learning Strategies used by EFL Students: The Case of 11th Grade High and Low Achievers at Jorgo Nole Preparatory School. Department of English Language and Literature, Institute of Language Studies and Journalism: Wollega University.

Hammerberg, D. (2004). Comprehension instruction for socio culturally diverse classrooms: A review of what we know. The Reading Teacher, 57, 648-658.

Kamil, M.L. (2004). Vocabulary and comprehension instruction. In P. McCardle and V. Chhabra. The voice of Evidence in Reading Research (pp. 213-234). Baltimore, MD: P.H. Brookes Publishers.

McCarten, J. (2007). Teaching Vocabulary Lessons from the Corpus Lessons for the Classroom ( $1^{\text {st }}$ Ed.). New York: Cambridge University Press.

Minda, M. (2003). The Effectiveness of Current Vocabulary Teaching Techniques in facilitating Production in junior Secondary Schools: Grade Seven in Focus. Addis Ababa University: Foreign Language and Literature.

MOE. (2005). Education Sector Development Program III (ESDP-III): Program Action Plan. Addis Ababa: Ministry of Education, Education Management Information Systems (EMIS).

Nation, I. S. P. (2001). Teaching and Learning Vocabulary. New York: Newbury House.

Nemati, A. (2009). Memory Vocabulary Learning Strategies and Long-Term Retention. International Journal of Vocational and Technical Education, 1(2), 14-24.

Pierce, M. E., and Fontaine, L. M. (2009). Designing Vocabulary Instruction in Mathematics, The Reading Teacher, 63(3), 239-243.

Rahim, R., and Shames, K. (2012). An Investigation of the Effectiveness of Vocabulary Learning Strategies on Iranian EFL Learners' Vocabulary Test Score. Department of English language, Islamic Azad UniversityTonekabon Branch, Tonekabon, Iran.

Schmitt, N. (2000). Vocabulary in Language Teaching: Cambridge Language Education. Cambridge: Cambridge University Press.

Siriwan, M. (2007). English Vocabulary Learning Strategies Employed. Rajabhat university students: Unpublished Doctoral Dissertation, the University of Suranaree, Malaysia. Retrieved from http://sutir.sut.ac.th:8080/sutir/bitstream/123456789/284/1/mayuree fulltext.pdf

Stahl, S. A., and Kapinus, B. (2001). Word power: What Every Educator Needs to Know about Teaching Vocabulary. Washington, D.C.: National Education Association.

Stahl, K. A. D., and Bravo, M. (2010). Contemporary Classroom Vocabulary Assessment for Content areas. The Reading Teacher, 63(7), 566-578

Walters, J. M. (2004). Teaching the Use of Context to Infer Meaning: A Longitudinal Survey of L1 and L2 Vocabulary Research'. Language Teaching, 37(4), pp. 243-252.

\section{Declaration}

I declare that this manuscript is my own work. I have followed all ethical principles of scholarship in the preparation, data collection process, data analysis and completion of the work. I affirm that I have citied and referenced all sources used in this manuscript. Very serious effort has been made to avoid plagiarism. 